First Peoples Child \& Family Review

An Interdisciplinary Journal Honouring the Voices, Perspectives, and Knowledges of

First Peoples through Research, Critical Analyses, Stories, Standpoints and Media

Reviews

\title{
Stuck in the Ways of the South: How Meritocracy, Bureaucracy, and a One-Size-Fits-All Approach to Child Welfare fails Nunavut's Children
}

\section{Patricia Johnston}

Volume 6, Number 1, 2011

URI: https://id.erudit.org/iderudit/1068897ar

DOI: https://doi.org/10.7202/1068897ar

See table of contents

Publisher(s)

First Nations Child and Family Caring Society of Canada

ISSN

1708-489X (print)

2293-6610 (digital)

Explore this journal

Cite this article

Johnston, P. (2011). Stuck in the Ways of the South: How Meritocracy, Bureaucracy, and a One-Size-Fits-All Approach to Child Welfare fails Nunavut's Children. First Peoples Child \& Family Review, 6(1), 66-82.

https://doi.org/10.7202/1068897ar

\section{Article abstract}

Based on qualitative research that explored the experiences of social workers in Nunavut's child welfare system, this paper examines the current approach to child welfare in light of a critical report issued by Canada's Auditor General in March 2011. Through a discussion of meritocracy, this study highlights the problematic approach to child welfare used by the Government of Nunavut, particularly in their reliance on Qallunaat or nonInuit social workers. The territory's current child welfare system, modeled on child welfare systems operating throughout southern Canada, does little to change the status quo and instead serves to maintain the colonial power structure in place for the last 50 years. This study determined that a unique and culturally relevant approach to child welfare is needed in Nunavut and Inuit traditional knowledge is essential is the move towards this important goal2.
This document is protected by copyright law. Use of the services of Erudit (including reproduction) is subject to its terms and conditions, which can be viewed online.

https://apropos.erudit.org/en/users/policy-on-use/ 


\title{
First Peoples Child \& Family Review
}

An Interdisciplinary Journal Honoring the Voices, Perspectives and Knowledges of First Peoples through Research, Critical Analyses, Stories, Standpoints and Media Reviews

Volume 6, Number 1, 2011, pp. 66-82

\section{Stuck in the Ways of the South: How Meritocracy, Bureaucracy, and a One-Size-Fits-All Approach to Child Welfare fails Nunavut's Children}

\author{
Patricia Johnston ${ }^{\mathrm{a}}$
}

a holds a Master of Social Work degree (M.S.W.) from the University of British Columbia, a Bachelor of Arts (B.A.), and a Bachelor of Social Work (B.S.W.) degree. She has worked as a social worker throughout the Canadian arctic, with the majority of her time spent in Nunavut. She is currently a registered social worker in Newfoundland and Labrador.

\section{Introduction}

In March, 2011, the Office of the Auditor General released a report on the state of social services in Nunavut titled Report of the Auditor General of Canada to the Legislative Assembly of Nunavut-2011: Children, Youth and Family Programs and Services in Nunavut (Office of the Auditor General of Canada, 2011). In this Report the Government of Nunavut's (GN) Department of Health and Social Services was criticized for failing to meet its responsibilities regarding the protection and well being of children, youth and families. The Report included responses from the Department of Health and Social Services regarding certain "problem" areas identified by the Auditor General's office, such as the Department "not complying with the procedures it has set for itself," one example being the inability to "track the current status of the children in its care" (Office of the Auditor General of Canada, 2011 , p.22, 23). These responses indicated the

Questions or correspondence concerning this article may be addressed to:

Patricia Johnston

patriciajohnston@live.ca

\begin{abstract}
Based on qualitative research that explored the experiences of social workers in Nunavut's child welfare system, this paper examines the current approach to child welfare in light of a critical report issued by Canada's Auditor General in March 2011. Through a discussion of meritocracy, this study highlights the problematic approach to child welfare used by the Government of Nunavut, particularly in their reliance on Qallunaat or nonInuit social workers. The territory's current child welfare system, modeled on child welfare systems operating throughout southern Canada, does little to change the status quo and instead serves to maintain the colonial power structure in place for the last 50 years. This study determined that a unique and culturally relevant approach to child welfare is needed in Nunavut and Inuit traditional knowledge is essential is the move towards this important goal².
\end{abstract}

Key Words: Nunavut; child welfare system; Qallunaat / nonInuit social workers.

Government of Nunavut agreed with all of the recommendations put forward by the Auditor General's ( $A G$ ) office. Yet rather than providing ground breaking advice and direction, many of the recommendations offered by the Office of the Auditor General appear to only describe in detail the problem the Government of Nunavut has faced for years. Namely, that the approach

\footnotetext{
1 This paper consists of excerpts from Patricia Johnston's MSW thesis titled When cultural competence is inadequate: an opportunity for a new approach to child welfare in Nunavut supervised by Professor Edward Kruk. It is available at https://circle.ubc.ca/handle/2429/12602?show=full. 2 This research received approval from the University of British Columbia's Behavioral Research Ethics Board (BREB) and licensing from the Nunavut Research Institute. As well, the Government of Nunavut's (GN) Department of Health and Social Services (DHSS), the Union of Northern Workers (UNW) and the Association of Social Workers in Northern Canada (ASWNC) were all advised of the research and asked to participate.
} 
to child welfare in the territory, including the standards and practices the GN set for itself, in an attempt to model service after the rest of Canada, has ultimately been its downfall.

Although these standards and practices have been in place since the creation of the territory in 1999 and the GN has reportedly not even come close to meeting them ${ }^{3}$, the Auditor General recommended in the Report that the Government of Nunavut should now finally meet them. Herein lies the problem. Or rather, what appears to be the problem, which is the difficulty the Government of Nunavut has had in turning Nunavut's child welfare system into a smaller version of other government child welfare systems currently operating below Canada's $60^{\text {th }}$ parallel ${ }^{4}$. However, this is not the problem at all. Instead, the problem lies in the government's refusal to do things differently. By neglecting to develop an approach to child welfare that is as unique to the territory, as the territory is to the rest of Canada, Nunavut has put itself in a terrible position. In fact, the territory is poised to continue to receive criticism regarding it's child welfare system as long as the Government of Nunavut continues to do as the Auditor General recommended: to attempt to meet the standards and practices it adopted from southern Canada.

In response to the Report, Nunatsiaq News, one of the territory's few newspapers, published an article titled Nunavut must do human resource plan, MLAs say, which highlighted some of the Auditor General's key recommendations (George, 2011). The article described how Nunavut must now grapple with requirements to "improve

3 One example of this is: "According to the Department's Program Manual on Group Homes in Nunavut, the Department must conduct yearly evaluations of the group homes to determine if they are meeting appropriate program standards to provide for the well-being of their residents. We reviewed whether the Department had conducted yearly evaluations during the 2008-09 and 2009-10 fiscal years. We found that no evaluation had been conducted on any of the group homes during this time" (Office of the Auditor General of Canada, 2011, p.20).

4 All provinces below the 60 th parallel are commonly referred to as southern, consequently, all people from the southern provinces are referred to as southerners. Since the use of the word "southern" is very common in Nunavut and it is regularly taken to mean all the practices, behaviors and thinking connected to a Euro-western and Canadian world view, the term "southern" has also been used throughout this paper. the human resource capacity" and address staffing shortages in the social work field, yet the statistics the article offered suggest a larger problem: meritocracy so embedded within the GN that despite the immense gains and successes Inuit have earned, including the creation of the territory itself, they remain at the margins. Within the article the most obvious example of this is despite the government's target of employing $53 \%$ Inuit by 2012, the number of Inuit in executive and senior management capacities has been decreasing over the past ten years (George, 2011). Equally concerning were the online public comments in response to the article, which included, "Stop resenting people who come here from the south, they are here for a reason. Want the better jobs? Get an education." As people responded to each other the list of statements grew to include "Some people don't get hired and sometimes they think it is because of race instead of because of merit... Hopefully, one day, everyone will be hired based on merit/the ability to do the job and everyone, regardless of race, will have the equal educational opportunities to do so." This last statement appeared to be considered by the others to be one of the more "progressive."

\section{The Real Problem}

This article in Nunatsiaq News and the Auditor General's Report highlight the real problem in Nunavut, namely the marginalization of Inuit, particularly regarding employment, within their own territory. The problem can be summed up as follows: Inuit are entitled by law to receive preference for employment yet they still occupy barely half of the government positions (Windeyer, 2010). Qallunaat, who make up only $15 \%$ of the population occupy the majority of government jobs, particularly in management, and routinely defend their positions, in a similar fashion to the responses of the Nunatsiaq News article, suggesting that Inuit do not possess the "education" or "merit" needed to do the job (Statistics Canada, 2006). This position is based on the fallacy that Qallunaat cling to: the belief 
that certain education is needed for the positions currently held within the territory by Qallunaat. It should be noted that this is not to suggest that certain positions do not require extensive training, but it is necessary to point out and to recognize comments regarding "merit" and "education" for exactly what they are: a means for continued marginalization.

In conversations among Qallunaat throughout the territory, it can often be heard how Inuit lack the "education" required to manage social services in their own communities. From this, it's not surprising that within the Department of Health and Social Services, Qallunaat hold the highest positions of directors, managers and supervisors. Working below them are again primarily Qallunaat social workers from southern Canada, while almost the entire client population remains Inuit. Based on this display of continued colonial power, it is also not surprising that discussions regarding the lack of social workers in the territory are consistently met with the solution of employing more Qallunaat social workers. Unfortunately, this same strategy has previously only lead to an increased reliance on "southerners" 5 in the Arctic, which has further served to continue the colonial relationship between Qallunaat and Inuit in place now for over 50 years (Thompson, 2008, Paine, 1971).

\section{A Unique Territory}

Yet if the norm throughout Canada is to fill the lack of social work positions with "qualified" social workers, one might ask: why should Nunavut be any different? The answer to this lies in Nunavut's uniqueness. In fact, Nunavut is so unique; it even stands apart from the other northern territories. This uniqueness begins with the territory's geography, for Nunavut has

5 Also directly linked to European ideology, the term "southern" in this text refers to scholars, practitioners and laypersons that, whether consciously or unconsciously, have absorbed a liberal European-based understanding of the world, now typical of the dominant "white" culture of Canada. A perspective that is "southern," therefore, within this paper is also used to make reference to a way of interacting with the world based on the many values and beliefs commonly associated with liberal Euro-Canadian culture, such as capitalism and individualism. the smallest population of all the provinces and territories, spread out throughout the largest area in the country, with not even one road connecting its many small communities to the south. The territory is home to $85 \%$ Inuit, $90 \%$ of whom speak fluent Inuktitut (Statistics Canada, 2006b) but perhaps most importantly, the significant cultural difference between Inuit and other Canadians are what contributes to the territory being so special.

One of the most fundamental differences between Inuit culture and the dominant culture ${ }^{6}$ in Canada for example, is that Inuit culture is based on values of collectivism, as opposed to the dominant liberal Euro-Canadian culture, such as capitalism and individualism. Despite awareness of this value base, it is not until one witnesses a mother give the last of her money to an extended family member, that this difference in perspective can be truly understood. If the family member asks and the mother has money to give, she gives. End of story. Except those who possess an individualistic perspective may question the mother's ability to care for her children once she has given the last of her money away and consequently may ask: how then does she feed her children tomorrow? In a communalist culture, someone else inviting the mother and her children for dinner answers this question. It is not a question of the mother's "ability or willingness" to care for her children, as child welfare workers from the dominant culture may perceive it. Instead, it is a caring and trusting way of living as part of a family, a community, and a culture.

Adding to Nunavut's uniqueness are the territory's challenging social issues, a significant lack of infrastructure, a unique justice system, and young legislation and organization within the territory. Upon arriving into one of the territory's remote communities, it becomes instantly apparent to Qallunaat just how different Nunavut is to southern Canada. It is a territory where hunting in the spring is essential to families,

6 Referring to the majority of Canada, where the way of interacting with the world based on the many values and beliefs commonly associated with liberal Euro-Canadian culture, such as capitalism and individualism. 
leaving school to take a back seat to this event for most Inuit children. It is this uniqueness that justifies and explains the need for a tailormade child welfare system and one not simply fashioned after the rest of Canada. Yet this is the missing piece within the Auditor General's Report, which ultimately leads the $A G$ away from the real problem Nunavut faces. For rather than continuing to apply a southern Canadian perspective and approach to child welfare to the territory, which has helped place the GN in a position where it could "not comply with the procedures it has set for itself," a new approach could provide the best possible child welfare system if it were indeed designed for the territory (Office of the Auditor General of Canada, 2011, p. 22). In fact, to truly address the many problems highlighted in the Auditor General's Report will first and foremost require moving away from the current one-sizefits-all approach to protecting children.

\section{Inuit Qaujimajatuqangit (IQ)}

Fortunately, a road map to resolving issues within Nunavut's child welfare system has already been drawn. Inuit culture and traditional knowledge can provide the direction, for Inuit epistemology or the theory of Inuit Qaujimajatuqangit (IQ), has been described as "a means of rationalizing thought and action, a means of organizing tasks and resources, [and] a means of organizing family and society into coherent wholes," (Arnakak, 2001). IQ is particularly important to Nunavummiut families today, as "the traditional kinship structure is the means whereby goods and services are transacted and exchanged" but it also is the "means of transmitting ideas, values, knowledge and skills from one generation to the next. In other words, individual, family and society are linked by the kinship structure" (Arnakak, 2001). Therefore, IQ or "that of which Inuit have known for a long time" is essential within child welfare so as to not damage the kinship structure, which underpins the transmission of culture between generations (Legislative Assembly of Nunavut, 2008).
The Government of Nunavut has recognized the importance of Inuit Qaujimajatuqangit and has reported on how it is incorporating IQ into the government workplace, while outlining the additional principles, values and directives for practice specific to the Department of Health and Social Services (GN, n.d.c). Unfortunately, the GN has described these priorities vaguely and has not expanded upon how social workers are to ensure their practice is consistent with IQ. This can be understood as providing very little guidance to the current Qallunaat social workers in Nunavut regarding the incorporation of $\mathrm{IQ}$ in their child welfare work. The Government of Nunavut has stated, "we will maintain positive innovations guided by Inuit knowledge, wisdom, values and beliefs" (GN, n.d.c, p. 44), but has yet to describe how this is to occur particularly when over half of the government workers are Qallunaat and do not possess Inuit knowledge, wisdom or values (Legare, 2008; Tester, 2006).

Fortunately, the Pauktuutit Inuit Women's Association's (2006) The Inuit Way, describes traditional methods of addressing issues within communities, such as how Inuit may have traditionally addressed issues with child welfare. The traditional methods for example, included the act of ignoring someone, mocking or shaming a person, the use of gossip, embarrassment and ostracizing someone who refuses to change their behavior. These approaches, among many others, historically worked to maintain community order while simultaneously maintaining the family unit by focusing on the behavior of the person or offence, with the basic rule being "that the punishment must not cause more problems for the group than the initial infraction" (Pauktuutit Inuit Women's Association, 2006, p. 19). The goal of these approaches were to maintain community balance.

Child abuse and neglect, when it occurred, was also traditionally addressed within extended family camps as Ekho and Ottokie (2000) describe:

Some of the parents had their children taken away, because the whole camp could see 
that the child was often very hungry and it was obvious that the child was being mistreated. Sometimes the child would be taken away and placed with another family. There are a few parents who only mistreat one of their children...so we have to show them love...they would tell the parents in a kind way that they would take the child for a while to provide for him or her. They would do this in a way so that the parents didn't start hating the child (p. 97).

Ultimately, Inuit Qaujimajatuqangit may, if truly given the opportunity to lead and give direction for the territory, show how a new approach, or rather a very old approach, to child welfare could better meet the needs of Inuit children, youth and families.

\section{Education and Training for Social Work in Nunavut}

The lack of "educated" Inuit social workers in Nunavut is routinely used to justify the employment of Qallunaat and in the past, this has led to the practice of Qallunaat social workers being recruited for Nunavut social work. Qallunaat social workers are typically educated through southern Canadian universities and have attended courses and workshops that incorporate learning on "cultural sensitivity" and "cultural competence." Yet these "culturally competent" southern Qallunaat social workers are trained in "dominant practice models...urban-designed and urban driven," which has invariably maintained "the social worker as colonial agent" who then "enforces metropolitan requirements on the hinterland" (Schmidt, 2000, p. 345). In fact, no university in Canada currently offers an education aimed at preparing Qallunaat for work with Inuit in Canada's arctic.

However, there is a college in Nunavut that provides a diploma to Inuit who are interested in working in the territory's social services ${ }^{7}$. Although this college graduates up to five

7 Some southern universities and colleges also offer courses directed towards Inuit entering the social work field. social workers a year (Legislative Assembly of Nunavut, 2007) and there have been over 10 years of graduating Nunavummiut (people of Nunavut) still only "half of the social workers in Nunavut are Inuit" (Legislative Assembly of Nunavut, 2008, p. 2961). Of the approximately 51 social work positions spread among the 26 communities in the territory, where typically only 33 positions are filled, it follows that there are less than 20 Inuit currently working in social work positions in Nunavut, while the other positions are either vacant or held by Qallunaat social workers (Legislative Assembly of Nunavut, 2008, p. 2961). The Auditor General's Report echoed this in its review of the almost $40 \%$ vacancy rate in the territory's social work positions. These numbers require in depth examination. They also raise questions as to why all of the college's social work graduates are not all employed in Nunavut, thereby eliminating the use of southern Qallunaat social workers altogether.

\section{New Racism and a Poor Fit}

This question regarding the lack of Inuit social workers may in part be answered by the fact that for most Inuit, being employed as a social worker may require working outside of their home community, while others might find working in their home community challenging due to their existing personal relationships. Augoustinos, Tuffin and Every (2005), however, provide another explanation as their research has shown "liberal principles such as individualism, merit, and egalitarianism" are "recurrently drawn upon to justify, argue and legitimate opposition to affirmative action" (p.315). Their research determined that for many in the dominant culture, the view of "Aboriginal disadvantage becomes similar to other situations in which disadvantages and setbacks can be overcome by hard work and application" (Augoustinos, Tuffin and Every, 2005, p. 331). This suggests the lack of Inuit social workers may be due to "new racism" within the Government of Nunavut and the high value placed on "the principles of individual achievement and 
meritocracy," which consequently "protects and maintains white privilege and leaves minority groups disadvantage intact" (Augoustinos, Tuffin and Every, 2005, p. 337). In addition to the very real "tension between Indigenous Aboriginal people and the predominantly European newcomers" (Schmidt, 2000, p. 341), Qallunaat are likely to be hired in a "leadership role" due to their "merit," thereby placing Inuit workers in a subordinate position to a southern colleague, which may have much to do with the lack of Inuit workers (Paine, 1971).

Research by Zapf (1993) regarding northern and remote social work practice in Canada provides an outline of what urban trained social workers from the dominant culture may experience when arriving to work in Canada's Yukon Territory from southern locations. Similarly, Schmidt (2008) provides a glimpse of northern social work through a study of social workers in remote communities of northern British Columbia. Together these two studies provide a picture of the challenges associated with southern social work models being practiced in Canada's northern communities. Both Zapf (1993) and Schmidt (2008) have shown that social work in Canada's north pose particular challenges for urban oriented social workers, such as retention and turnover, largely owing to a "poor fit between urban-based professional social work training and the realities of northern communities" (Zapf, 1993, p. 694). Southern social workers reported difficulty with "the lack of anonymity, high visibility, isolation, and the poverty of amenities" (Schmidt, 2008, p. 104) and this "poor fit manifests itself in the field as a stressful choice perceived by the worker as he or she comes to view the requirements of the job as incompatible with active membership in the community" (Zapf, 1993, p.696). This conflict results in what Zapf (1993) refers to as the experience of "culture shock."

Schmidt's (2008) research determined that social workers reported issues of personal safety within communities and "personal health being threatened by the stress of the work" as well "the constant challenge of trying to meet standards that are impossible given staff shortages and workloads" (p. 102-103). These stressors and the culture shock associated with working in remote Canadian communities led Zapf (1993) to the overall conclusion "that the difficulty may not be an issue of the wrong people in the north as much as a question of the role of conventional social work itself in the setting" (p.701). Social workers respond by attempting "to understand the community using frameworks from his or her own familiar culture and profession" (Zapf, 1993, p. 702). The southern or dominant world view, values, and the beliefs held by social workers and their use of southern based practice standards inevitably lead to "the futile feeling of trying to do a job that cannot be done according to standards because the human resources are simply not there" (Schmidt, 2008, p. 100). Although Zapf's (1993) and Schmidt's (2008) studies provided useful information as to the challenges and issues associated with providing southern social work to remote Canadian locations by southern social workers, both omitted a discussion of the culture of communities, the power inherent in the role of social worker, colonialism, or the role of social work as colonial agent.

\section{Becoming Educated}

Another possible answer to the lack of Inuit social workers employed in Nunavut may lie in the training Inuit receive at Nunavut's Arctic College. For example, although the college holds cultural components within it's programming, it is unlikely that the social work program is focused on "the decolonization of Aboriginal people, which is enacted through methodology that contextualizes colonization, and integrates healing methods based on Aboriginal epistemology" (Sinclair, 2004, p. 55). This is because the college's current human service or social work program is "considered bi-cultural in the sense that it attempts to incorporate the orientations and values of traditional First Nations culture with the dominant values of Euro-Canadian society" (Durst, 2006, p. 10). Interestingly, this choice of First 
Nations culture rather than Inuit culture highlights the use of southern mainstream cross-cultural education. Although this could be understood as a positive sign of "Indigenous themes entering mainstream social work discourse" (Grey, Coates and Hetherington, 2007, p. 60), social work education in Nunavut remains "mainstream" as it comprises dominant culture educators, dominant culture course work and materials, dominant culture theories, approaches, interventions, expectations, and values and beliefs (Nunavut Arctic College, 2008b). This value base is clear within the college's programming, which includes "post-modern counseling and capacity building techniques" and employs Qallunaat instructors to teach the programs (Nunavut Arctic College, 2008a). The curriculum also includes standard mainstream courses commonly taught at southern Canadian Universities including "Social Work Methods," "Interpersonal Communication Skills," "Human Development," "Applied Counseling Skills," "Theories of Counseling," and "Sociology: Family Dynamics" to name a few (Nunavut Arctic College, 2008b).

In addition to this, the Nunavut Arctic College requires the majority of students to have "completed grade 12" and "submit a letter" in application, possibly submit to "a security clearance" and be "required to write" 8 a proficiency exam to enter the social work program (Nunavut Arctic College, 2008b). These entrance requirements indicate that the college's social work program is more congruent with southern Qallunaat educational institutions than the "principles and values of IQ" and the Nunavut Land Claims Agreement regarding a reduction of barriers to Inuit. Surely the college recognizes how asking these entrance requirements of Inuit who come from a verbal culture, may have in part led to the criticism that "Nunavut schools are essentially foreign institutions delivering a foreign curriculum in a foreign language" (Legare, 2008 , p. 365). Creating further challenges is the southern model of education in place in Nunavut, for "following natural rhythms make the artificial schedule of the Qallunaat school especially

8 Emphasis added. difficult for some Inuit" particularly when there is daylight or darkness for 24 hours during certain times of the year (Berger, Epp and Moller, 2006, p. 188). Along these same lines, even the "structure of curriculum in Qallunaat schools [is] hierarchical and therefore problematic" (Berger, Epp and Moller, 2006, p. 188) and for the majority of Inuit, they are required to leave their home communities to access "training" by Qallunaat in the larger communities (Inuit Tapiriit Kanatami, 2005).

Inuit that do attend Nunavut's college to become social workers are also required to learn southern social work theory and then learn to practice social work consistent with southern universities and colleges (Nunavut Arctic College, 2008 b). It is possible that this may be counterproductive to the employment of Inuit social workers and may even discourage those who would be appropriate for Nunavut social work because "unless we train the 'natural' out of their style, it is assumed that they will operate in a culturally-sensitive way and likely to remain in their communities" (Berman, 2006, p. 103). For "even without formal training, villagers can better identify problems and write better case histories" than southern social workers who have been selected for their extensive education and cross. cultural practice experience (Berman, 2006, p. 102). This is likely because "they have grown up with clients, are better at monitoring situations on a daily basis," and "their work is likely to be compatible with the culture and lifestyles of their clients" (Berman, 2006, p. 102). One thing is clear; the lack of Inuit employed within the Government of Nunavut's child welfare system is more than just hiring "based on merit/the ability to do the job." In fact, it raises the question of who really needs to become educated?

\section{The Study}

The desire to look critically at child welfare in Nunavut, which led to this research, stemmed from my personal experience as a social worker in the arctic. In particular, it grew from the discomfort of being expected to apply my southern 
Canadian based knowledge of child welfare to the communities I visited. From this experience, I realized quickly that I represented the colonial power in the territory, the authority, and for many Inuit, my arrival in their community likely conjured up fear and discomfort. This was a far cry from the feelings associated with wanting "to help" that initially brought me to the social work profession. Yet I participated in the Government of Nunavut's struggle to meet standards and procedures until the lack of relevance the current child welfare approach had to the community became so apparent that I could no longer turn a blind eye. It became clear how the government's goal of creating a replica of southern child welfare in the north was not only not culturally relevant, but worse, striving toward this goal was "pushing Inuit out of a relatively embedded culture into the disembedded culture that is our own" (Irniq, Rowley and Tester, 2006, p. 5). After witnessing grandmothers in Nunavut communities do child welfare work, and by this I mean intervening when parents were unable to care for children, I believe I have see first hand how this approach works better for families, but even more so for children, compared to the current meritocratic, bureaucratic, and one-size-fits-all approach to child welfare being sought after by the government. Therefore, this study went in search social workers thoughts, perspectives, experiences, and opinions on child welfare in the territory. What were their experiences of social work in Nunavut? Did any of them, like me, question the current direction?

\section{Method}

As the research topic for this study involved exploring the experiences of social workers, it was appropriate that participants be provided with an opportunity to state their thoughts through open discussion, which consequently allowed for a greater understanding of the context in which they work. Since the information sought out was focused on developing a deeper understanding of child welfare, it was essential that detailed information be collected. Selecting a qualitative study was key to collecting this information (Grinnell and Unrau, 2005). As there is very little known about child welfare in Nunavut within academic social work discourse, this study sough to obtain social workers' perspectives and to do so, participants were provided with the time and space to describe their experiences through semistructured open-ended interviews.

A grounded theory approach that drew on elements of phenomenology was selected to better understand the subjective experiences of the social workers interviewed, particularly regarding their relationships, the environment, and working in Nunavut's remote communities. This approach was selected as phenomenology seeks to deepen our understanding by delving into the "truths" of the participants' experience through descriptive investigation, while grounded theory seeks to collect these truths to gain explanation and better understanding (Grinnell and Unrau, 2005). This is an ideal way to explore how social workers experience child welfare in Nunavut, as each participant can provide unique and subjective information based on their work, their personal feelings, values, and beliefs, making up their overall view of child welfare work in Nunavut. Grounded theory was also appropriate to this research, as it can involve the experience of the researcher as well as the participants. As I have personal experience working as a social worker in Nunavut, and therefore fall within the population group being studied, I am also able to provide my thoughts and reactions within this research method (Grinnell and Unrau, 2005). Using my own experience as a starting place, I sought out social workers' experiences to determine linkages, patterns, themes and overall theories that could emerge from the data.

Unfortunately, despite the intent to interview both Inuit and Qallunaat social workers, almost all of the participants were Qallunaat ( $9 / 10$ social workers interviewed), which is likely a consequence of the research design as "it was not reasonable to assume that [Inuit social workers] would have unqualified confidence in, or be comfortable with, the methodology, the researcher, or the 
interview process" (Berger, Ross Epp and Meller, 2006, p. 185). Research in Inuit communities has left negative feelings between Inuit and researchers due to studies where the information was not provided back to the communities. Similarly, when outsiders conduct research in northern communities "without co-creating the agenda with insiders," or at least inviting Inuit perspective has also led to "doing more harm than good" and has not fostered relationships built on trust and respect (Berger, Ross Epp and Meller, 2006, p. 184). Although this research was not conducted in Nunavut, it still pertains to the territory and to Inuit, and I am, therefore, at fault for not seeking Inuit input and collaboration in the research design. In retrospect, it is easy to understand how the lack of "insider" discussion, Inuit perspective and community collaboration into the development and design of this research likely had a large role to play in who volunteered to participate. Therefore, by not involving Inuit in the creation of this study likely led to the final product, which is a study conducted by a Qallunaaq researcher (myself) regarding of, for the most part, experiences of Qallunaat social workers. Consequently, this study does little to reduce the dominant culture discourse regarding Canada's Inuit people. It does, however, serve to examine the limitations and challenges of the current approach to child welfare, as well as the Government of Nunavut's reliance on Qallunaat social workers as colonial agents of social control.

Over the course of one calendar year, participants were obtained via convenience, criterion, and snowball sampling methods, resulting in a total of 10 interviews. Each interview took place via an Internet telephone or Voice Over Internet Protocol (VOIP) software known as Skype so as they could be recorded on another computer software program called Trx Recorder. This data collection method was selected due to the lack of opportunity to meet in person and the large distance between researcher and participants. I conducted each interview while I was physically in Vancouver, British Columbia, with the participants physically in Nunavut or spread across Canada. Interviews ranged from 45 minutes to a little over one hour in length and were scheduled at the participants' convenience. In two cases, interviews were cut short due to the employment demands of the participants and second interviews were scheduled. All participants were offered transcripts of the interviews, but only one participant was interested in this and was subsequently provided with the transcript of the interview. This participant did not make any comments upon review of the transcript.

Unfortunately, as I am unilingual and cannot speak Inuktitut and because the employment of a translator was not financially possible for this study, all interviews were conducted in English. Should Inuit social workers wished to participate in Inuktitut, it is possible that a translator could have been achieved within their community, however, in hindsight, I now recognize that this was not indicated through the means of recruitment. Therefore, it is possible that some Inuit social workers did not wish to participate or believed they were not able to participate due to the requirement of speaking English. It is also possible, that because the research was designed to use questioning, and because some "Inuit may perceive direct questioning as invasive" some Inuit social workers may have chosen not to participate for this reason (Berger, Ross Epp and Meller, 2006, p. 185). Finally, my personal involvement and employment in Nunavut may have presented the largest limitation, for when I was in the territory I was employed as a Supervisor of a number of different communities. It would follow that some participants may have felt guarded in terms of how much information they were willing to share with me due to concern that it could impact our working relationship. In addition to this, I am Qallunaaq from southern Canada, which likely had an impact on Inuit social workers' ability to trust me to conduct respectful research. As well, some social workers may have simply not wished to participate, due to our current or previous working relationship. 
Due the very nature of discussing one's employment, additional attempts were made to maintain the anonymity of all participants. In this way, it was hoped that all participants could freely describe their thoughts and experiences without reproach. Therefore, this research served as an opportunity to begin discussions and share comments in a confidential environment. In order to maintain confidentiality of all participants the majority of demographics of participants have been withheld. This is because there are so few social workers that have worked or are working within Nunavut's child welfare system that by distinguishing gender, age or even the communities participants worked in could add to the likelihood of their identities being determined. However, it can be noted that the participants were both male and female, 90\% were Qallunaat and 10\% Inuit, currently $50 \%$ were living in Nunavut and $50 \%$ were living outside of the territory, and all have worked from short term (less than six months) to long term (many years) within Nunavut's child welfare system. Participants also held a range of education and experience prior to their work in the territory and all had been employed as a social worker at some time in Nunavut.

Due to my personal involvement in Nunavut's child welfare system and my connection to the work, the north and even the participants, it was that much more important to let the experiences of the participants guide this research, so as to ensure that my personal bias did not lead, nor determine, the findings. Using the constant comparative method, commonly known through work by Glasser and Strauss (1967), to develop categories, the data collected was transcribed, coded, and grouped into categories and themes and from this theories have emerged. To do this I began by looking for key issues and recurrent events, such as perspectives or experiences that were common among participants. During analysis there were 19 overall categories that had developed through interviews with participants, but the categories that generated the most responses included: "description of role and work," "education and training," "expectations and first impressions," "funding and resources," "concerns with child welfare in Nunavut," "safety, stress and discomfort," and "worker turnover and employment." This method helped to ensure that the information collected from all participants, and not my own prior hypothesis or assumptions, was truly the driving force of the research.

Keeping in mind that data collection is "particularly vulnerable to biases of the data collector," I was careful to reflect upon each interview and collected content, and note my personal reactions and biases (Grinnell and Unrau, 2005). In order to reduce my biases and ensure the credibility, transferability, and dependability of the research, I articulated data collection decisions. Also, my prolonged engagement through participant observation has provided me with access to the culture of the participant population. By conducting interviews to the point of saturation and providing a review of the pertinent literature, I demonstrated a basis for the research. Through explicit and thick descriptions of data I also aimed to bring the reader into the text as much as possible.

\section{Findings}

\section{Heading North}

This research study uncovered a number of issues related to social work employment and training within the territory. The Qallunaat participants interviewed all reflected on their preparation for working in Nunavut and their feelings of being unprepared for the difficult work required of them. Consistent with the findings of the Auditor General's Report, all of the participants interviewed for this research indicated that there was no orientation or training provided to them to prepare them for child welfare work in the territory, and what skills, perspectives and understanding of child welfare each social worker brought to their social work practice was entirely up to them. Despite the range of experience participants held, only one participant indicated there was training during 
their entire employment with the Government of Nunavut. Another participant was provided with "about an hour overview" and then was handed a "caseload I would be covering and a couple of the significant cases and what I should start off doing that day." Another explained, "They pretty well gave me a day to look over the legislation, to look over the policy manual." Finally, one participant was provided with "a tour of the town of [community $\mathrm{x}$ ] and introductions to the RCMP and a tour of the health centre and introductions there. [This community] also had a [additional resource] so we also went there. So that was my orientation. That was my introduction....and then I was off and running." This lack of orientation or training provided to Qallunaat is concerning, particularly as it suggests Qallunaat are expected to know how to do child welfare work within an Inuit community, despite never having lived or worked in the territory before. The last comment raises an even greater alarm for it indicates that the orientation to the work involved a Qallunaaq social worker being introduced to other Qallunaat in the community who hold decision-making power, such as the medical professionals and the RCMP, thereby reaffirming the status quo.

For those participants that came to Nunavut from southern Canada, there was no discussion in advance of beginning their employment about what they would be doing upon arrival. Consistently, the experience included "absolutely nothing. I was told that I would have $[\mathrm{x}]$ amount of weight [in luggage]. The government was more concerned with what I brought up with me and my packing than what I was going to be doing when I got there and I assumed I would be trained but I wasn't." Another participant stated, "I sent a resume, got a telephone call and a month later I was on a plane and I had no idea what to expect, knew nothing about Nunavut" which was again similar to the experience of another participant who stated, "there was no information session, there was no training, oh God there was no training, there was let alone any cultural acclamation or anything like that, you were really like in a sink or swim situation you know, and you have to learn the culture or you don't." Overall, it became clear how the preparation for work in Nunavut, including any education regarding Inuit culture, the social context and history of the territory, and relevant perspectives or ideologies to child welfare was entirely up to each Qallunaat worker.

\section{Necessary Knowledge and Training for Child Welfare Work in Nunavut}

Despite the lack of preparation or training for the work, the importance of having an understanding of Inuit culture was raised by a number of participants. When looking back to first arriving in Nunavut, one participant described how not understanding Inuit culture was evident in an interaction with a child:

That whole raised eye brows is 'yes' and scrunch your nose means 'no' and I remember asking a little girl something and...she raised her eyebrows...I [thought] that she couldn't hear me so I asked her again only louder. So she raised her eyebrows again until I was like screaming at this girl wondering if she needs to go the health centre because no one has checked her for a hearing disorder. And she was like 'I'm saying yes.' And that's so simple, like that is so basic. That's not even a nuance part of the culture and nobody tells you that!

The Inuk participant added to this sentiment by explaining that for those working in child welfare an understanding of Inuit culture is essential because, "There are things that maybe a white person or social service worker doesn't understand [about] our culture or our traditions. [If they] come up here and see some of the things and how we treat or raise our children and you know kind of maybe see it as neglect or but it's just the way." This participant's comments are essential to the discussion on child welfare and clearly indicate how misunderstandings can occur when Qallunaat social workers lack an understanding of Inuit culture and operate from a southern world view of childrearing. As 
apprehension of children from their families is an intervention social workers are able to use when they believe it to be necessary, it becomes clear how misunderstandings regarding culture can hold enormous implications for children and families.

Although most participants described initiating and seeking out informal means to prepare themselves for their job, even after doing this, none of the Qallunaat participants indicated they had any solid understanding of Nunavut prior to arriving there for work. "Everything I know about Nunavut, I learned once I got here," explained one social worker. Many participants indicated that they learned "on the job" and described how local Inuit community members or other Inuit staff trained them or helped them get acquainted with child welfare work in the territory. As one participant explained:

the secretary and the [other staff person] fully trained me, and completely trained me very well to the resources in the community and who the people are and that [was] not anything I would have gotten out of a policy manual. And they taught me how to do my job in a respectful way and I really had to listen to the people of the community because they have been doing this for thousands of years and even just the past ten years when you haven't been in that community and they know who the people are."

Another participant confirmed this reliance on the Inuit support staff for essential training as, "the person with the most experience was the secretary and she quite literally trained both of us." The positive associations social workers held to being trained by support staff came through clearly in the interviews. Interestingly, the Government of Nunavut's failure to train new Qallunaat social workers, perhaps out of a reliance on their education and "merit" in southern Canada, led to the unintended result of blurring or exchanging of roles between Inuit and Qallunaat. This left southern educated Qallunaat social workers to exchange their role of "expert" for the role of "student."

\section{Culture Confusion}

In addition to their lack of knowledge about Nunavut, many participants described their arrival in the territory as disorientating. One participant explained, "I remember the day I got off that plane and I realized that I have no idea where I am or what I am doing." The feeling of disorientation and cultural confusion were consistently described by Qallunaat, as another social worker recalled "it was like a shock after shock after shock." One participant described their arrival in Nunavut as, "a fly by the seat of your pants situation. And I think I would say I was in a daze for about two weeks of just, like sheer culture shock where I was just, like it's almost like a hazy experience when I look back." Despite the "shock" of arriving, social workers described feeling an expectation to begin working in a culturally specific way immediately upon arrival. Yet one participant described an inability to rely on their previous social work practice, knowledge and skills:

I would say, child welfare, you can't- your practice is hard as it stands especially with the lack of resources, the sheer lack of resources is- you know there are times when I didn't apprehend kids because I didn't have the foster parents and I knew I didn't have the foster parents so I'm not taking these kids and we're going to have to go down another route. Maybe I should have maybe I shouldn't have, maybe should have taken them and put them in another community, but you can't just practice your practice.

This realization that "you can't just practice your practice" is indicative of how southern social work is not transferable and may even be inadequate and culturally unspecific to Nunavut. Equally as important, this issue of Qallunaat being unprepared to work in Nunavut and begin practicing in a culturally relevant way was, 
perhaps obviously, not raised by the Inuk social worker. Instead, this social worker commented instead on the needs of the community not being addressed through the current approach to child welfare in the comment, "parents themselves are not being heard."

Closely connected to this was a comment by another participant who stated:

people knew exactly what the issues were and what they should be doing, but it seems to me that it wasn't an easy, it wasn't easy to effect change in the way that we're talking about...I think that the [senior staff persons] that were in place, were just basically I mean trying their best to keep standards in place and to keep the ship afloat. You know. And to respond. And that's one of the reasons too that I think that you know it is a child protection act and because with those types of resources you don't have much choice.

Although this comment by a Qallunaaq social worker recognizes the community possesses knowledge of social issues, the participant neglects to envision another approach or perspective other than the southern colonial model and keeping "the ship afloat." This further suggests that not only is southern child welfare education, experience and training not necessarily relevant to child welfare in Nunavut, this comment may be indicative of the larger problem: namely the belief that there is no other "choice" to the current child welfare approach.

\section{Discussion}

\section{A Faulty Argument}

Many Qallunaat and Inuit alike have accepted that solutions to some of Nunavut's social issues should include incorporating Inuit culture into government programming while focusing on training and employing Inuit to "take over" the role of social worker from Qallunaat workers (Timpson, 2006). This solution, however, appears to be rooted in beliefs that "the recruitment process of government staff has been plagued by a shortage of qualified Inuit professionals" and "the problem is more than half of the government positions require college or university training" (Legare, 2008, p.357). In fact, the solution of training Inuit to fill social work positions is indicative of the dominant culture's lack of an alternative world view, including the belief and reliance on southern training or education as necessary and the only acceptable solution. This perspective is further based on "meritocratic ideals presented as 'consensual' values that were central to a fair and just society that treats everyone equally" (Augoustinos, Tuffin and Every, 2005, p.319). In this same line of thought, many Qallunaat social workers justify their work in Nunavut as necessary until "trained" Inuit are available to take over the social work position within the communities. Yet this research with social workers in Nunavut indicted the opposite, for not only did Qallunaat end up relying on Inuit to teach them how to do child welfare work in Nunavut, Qallunaat social workers identified that their past education, experiences and training were not necessarily relevant nor applicable to working in the territory.

As Qallunaat participants recognized in this study that they were unable to practice social work as they did in southern Canada, they found themselves being trained and educated by Inuit staff and the community. This was not to say that social work education is negative, or that there is nothing to be learned from southern Canada or southern education methods. Instead, it is to suggest that the role of social work education in Nunavut could be culturally relevant if educators "conceptualize education as a dialogue between the educator and students -a process in which both learn and are changed" (Green and Dumbrill, 2005, p. 173). This exchange and process of learning could be transcended to child welfare practice, particularly as the Inuk social worker interviewed in this study stated so clearly, "parents themselves are not being heard." For it is clear who is being heard. The dominant culture and their perspective of how the territory's child welfare system should be organized and controlled, is 
made even louder when it is reaffirmed in the Auditor General's Report. Instead, recognition of community knowledge and experience is required and should play heavily into who is provided with the decision making power regarding Inuit children within the territory. However, as long as Qallunaat continue to rely on the argument of "merit" as why Inuit do not hold the majority of power in the territory, both social work and social work education will only continue to act as "instruments of assimilation to western culture" (Berger, Epp and Moller, 2006, p. 196).

\section{Bureaucracy and Meritocracy}

The perception that Inuit require college or university level social work training to do child welfare work within their own culture, communities and with their own people is an example of "indigenization as a bureaucratic reform measure aimed at integrating Indigenous minorities into the imposed system of social control by coopting Indigenous people to enforce laws of the state" (Litwin, 1997, p. 334). It also raises the question: is the profession of child welfare not simply about keeping children safe and ensuring their wellbeing? One has to ask, is lengthy formal education necessary to meet this goal? Is the kind grandmother who knows everyone in her community, the history, strengths and challenges each person faces, and is respected by all, not qualified to do this work? If so, for whose purpose does the bureaucracy serve? Surely the Government of Nunavut, criticized in the Auditor General's Report for "not keeping track" of the many children in its care, would agree that their bureaucratic approach is flawed (Office of the Auditor General of Canada, 2011). Unfortunately, in response to this criticism, the Government of Nunavut indicated, it is now preparing to launch new computer software aimed at increasing the ability to "track" children in its care. This response will ultimately serve to increase the bureaucracy and create the need for an even greater requirement of "education" related to computer skills for its workers.
Indeed, the meritocratic hiring of social workers and the requirement for a bureaucratic process in the Government of Nunavut needs to be questioned, for it is clear that it is not even meeting its own needs. But as this research has shown, the move towards replacing Qallunaat social workers with Inuit social workers is also not the answer. In fact, this move is similar to what many Aboriginal child welfare agencies in southern Canada, who which have completed this replacement only to find it served to "compound the oppression of Indigenous people within an operational context which paradoxically, by appropriating Indigenous personnel, manages to enhance the legitimacy of state intervention" (Litwin, 1997, p. 335). Ultimately, such a move by the Government of Nunavut seeks to turn Inuit into the "family police" of their own communities. Where instead, recognition of Inuit traditional knowledge and community understanding as more specific to Nunavut child welfare, than southern education and training, is the starting place for a real solution.

Although education was not the entire focus of this study, it is important that we remember how it "has been used as a pretext for removing Aboriginal children from their communities and indoctrinating them in western/European knowledge systems. Even though residential schools no longer exist, [the current] educational systems remain steeped in Eurocentric knowledge" (Green and Dumbrill, 2005, p. 171). We must also remember the "bias in education is often invisible to those from the dominant western culture because society is so steeped in this culture that western ways can appear to be "normal'" (Green and Dumbrill, 2005, p. 171). The desire by the Government of Nunavut to mimic child welfare systems in other provinces and territories is an injustice to Inuit who deserve a system that does more than just "keep the ship afloat." This desire also signals a denial of Inuit capacity to develop a truly unique culturally relevant child welfare system. Even as the Auditor General's report recognized that Qallunaat social workers require an understanding of "Inuit societal values," this 
still falls short of the real answer to Nunavut's need for a "human resource plan:" to recognize Inuit as experts on the protection and wellbeing of their own children.

\section{A Necessary Change}

Dismantling colonial relationships and moving toward Inuit possessing the decision-making power and control over the protection of Inuit children, in line with Inuit culture and traditional knowledge, will no doubt be challenging. This is because "the more widespread, the more unsettling, the more radical the change, the more intensely it will be resisted," particularly when change "call[s] for organizations to dissolve or to reconstitute in some basic way" (Wharf, 1979, p. 18-20). Resistance to a different approach to child welfare can also be expected, as it will require a departure from the notion of social worker as "expert" and relinquishing the power Qallunaat hold within their roles as child welfare workers. A new approach to child welfare will also require:

forfeiting status, comfort, and certainty as one who has access to the 'true' reality and the authority to dispense that truth... It means a shift in thinking away from the comfortable idea that there are 'right' methods of practice, towards the idea that methods and practices can be improvised to fit each community's unique, dynamicallychanging contextual demands (Sellick and Delaney, 1996, p. 42).

Giving up power is not something likely to be comfortable for those who have embedded beliefs of their personal status due to their education and years of experience within the working environment. But it is this very notion of a social worker's education and experience or "merit" that is the foundation of the subtle "new racism" that meritocratic logic holds, which ultimately prevents social change (Augoustinos, Tuffin and Every, 2005).

Moving away from a western view of merit is a necessary step towards Inuit self-government and reversing the current flow of power in Nunavut communities. Elders and community healers in the territory are unlikely to hold degrees or certificates in healing, counseling or social work, and young community members that might obtain the necessary education or credentials may not be recognized in such respected roles due to their young age and lack of experience (Pauktuutit Inuit Women of Canada, 2005). In order to view Inuit elders and healers as qualified and able to teach, heal and support, requires abandoning the southern meritocratic paradigm currently being upheld in Nunavut by the dominant culture. Moving beyond the view of credentials, resumes and formal "experience" will be necessary to the development of a new child welfare approach within the territory. This move will naturally be difficult for those who "still cling to a value system that cherishes rugged individualism and extols the myth that Canada is an open society in which anyone can succeed with the requisite amount of hard work and determination" (Wharf, 1990 , p. 174). However, until a move away from meritocratic thinking to the "very opposite of the hubris which so often accompanies academic training and expert status," the status quo in Nunavut will be unable to change hands (Sellick and Delaney, 1996, p. 42).

\section{Conclusion}

The Auditor General's Report, if created for anywhere but Nunavut may have been useful. Unfortunately, the Report only suggested Nunavut continue to do more of the same thing; a plan that clearly has not been working. Through interviews with social workers in the territory and examining the meritocracy within the child welfare system, this research concluded that the Government of Nunavut (GN) has not just failed to protect children. By continuing to mimic southern Canada's child welfare systems, the GN has simultaneously maintained the territory's status quo and eliminated opportunities for parents to be "heard." Nunavut's current approach has also neglected to address the real problems in Nunavut, such as the continued marginalization of Inuit 
within their own territory. The overall result is a child welfare system that lacks cultural relevance to Inuit. Fortunately, Inuit Qaujimajatuqangit (IQ) is able to provide the direction for designing a child welfare system for the territory. From this, a different approach to child welfare in Nunavut, one based on traditional knowledge, Inuit culture and overall well-being, may just provide what the Auditor General, the Government of Nunavut, Qallunaat social workers and all Nunavummiut collectively want for the future: a system that truly works to protect Inuit children.

\section{References}

Arnakak, J. (2001). What is Inuit Qaujimajatuqangit? Using Inuit family and kinship relationships to apply Inuit Qaujimajatuqangit Retrieved March 1, 2009 from Canku Ota Web Site http://www.turtletrack. org/Issues01/Co01132001/CO_01132001_Inuit. htm.

Augoustinos, M., Tuffin, K. \& Every, D. (2005). New racism, meritocracy and individualism: Constraining affirmative action in education. Discourse and Society. 16 (3), 315-340.

Berger, P., Epp, J.R. \& Meller, H. (2006). The predictable influences of culture clash, current practice, and colonialism on punctuality, attendance, and achievement in Nunavut's schools. Canadian Journal of Native Education. 29 (2), 182-205.

Berman, G. S. (2006). Social services and Indigenous populations in remote areas: Alaska Natives and Negev Bedouin. International Social Work. 49 (1), 97-106.

Durst, D. (2006). Social welfare and social work education in Canada: Implications for Canada's north. International co-operation in social work and social policy. Regina, Saskatchewan: School of Social Work, University of Regina.

Ekho, N. \& Ottokie, U. (2000). Special cases. Chapter 7. In Briggs, J. (Ed.), Interviewing Inuit elders: Childrearing practices. Volume 3. Iqaluit, Nunavut: Nunavut Arctic College.

George, J. (2011). Nunavut must do human resource plan, MLAs say. Nunatsiaq News. Retrieved March 26, 2011 from http://www.nunatsiaqonline.ca/ stories/article/03047_nunavut_must_produce_a_ human_resource_plan_standing_committee_says/.
Government of Nunavut. (n.d.). Inuit Qaujimajatuqangit in the government of Nunavut: First report 1999-2003. Retrieved March 9, 2009 from http://www.gov. nu.ca/cley/english/pdf/IQ\%20Annual\%20Report. Eng.pdf.

Green, J., \& Dumbrill, G. C. (2005). A child welfare course for Aboriginal and non-Aboriginal students: Pedagogical and technical challenges. Journal of Technology in Human Services, 23 (3/4), 167-181.

Grey, M., Coates, J. \& Hetherington, T. (2007). Hearing Indigenous voices in mainstream social work. Families in Society: The Journal of Contemporary Social Services. 88 (1), 55-66.

Grinnell, R.M. \& Unrau, Y.A. (2005). Social work research and evaluation: Quantitative and qualitative approaches. $7^{\text {th }}$ Ed. New York: Oxford University Press.

Inuit Tapiriit Kanatami. (2005). State of Inuit learning in Canada. Ottawa, Ontario: Canadian Council on Learning, Socio-Economic Department. 1-10.

Legare, A. (2008). Canada's experiment with Aboriginal self-determination in Nunavut: From vision to illusion. International Journal on Minority and Group Rights. 2 (15), 335-367

Legislative Assembly of Nunavut. (2008). Bill 23, Appropriation (operations \& maintenance) act, 2008-2009, Consideration in Committee, Health and Social Services. Parliamentary debates (Official Hansard), official report, $4^{\text {th }}$ session, $2^{\text {nd }}$ assembly. Iqaluit, Nunavut: Legislative Assembly of Nunavut. 2915-2987.

Legislative Assembly of Nunavut. (2007). Oral Questions, 006- 2(4): Return to written question 020- 2(3) Social worker positions in Cambridge Bay. Parliamentary debates (Official Hansard), official report, day 1, Tuesday, March 6, 2007. Iqaluit, Nunavut: Legislative Assembly of Nunavut. 1-51.

Litwin, J. (1997). Child protection interventions within Indigenous communities: An anthropological perspective. Australian Journal of Social Issues. 32 (4), 317-340.

Morrissette, V., McKenzie, B. \& Morrissette, L. (1993). Towards an Aboriginal model of social work practice: Cultural knowledge and traditional practices. Canadian Social Work Review. 10 (1), 91-107.

Nunavut Arctic College. (2008a). Human services. Arviat, Nunavut: Nunavut Arctic College. Retrieved June 19, 2009 from http://www.Arcticcollege.ca/ news/News_eng.aspx?ID=32. 


\section{Stuck in the Ways of the South}

Nunavut Arctic College. (2008b). Calendar of courses: 2009-2010. Arviat, Nunavut: Nunavut Arctic College. Retrieved June 19, 2009 from http://www. Articcollege.ca/publications/calendars/261154_ english.pdf.

Office of the Auditor General of Canada (2011). Report of the Auditor General of Canada to the Legislative Assembly of Nunavut-2011: Children, youth and family programs and services in Nunavut. Ottawa: Retrieved March 26, 2011 from http://www.oag. bvg.gc.ca/internet/docs/nun_2011-3_e_35006. pdf.

Paine, R. (Ed.).(1971). Patrons and brokers in the east Arctic. Newfoundland: University of Toronto Press.

Pauktuutit Inuit Women's Association. (2006). The Inuit way: A guide to Inuit culture. Ottawa, Ontario: Pauktuutit Inuit Women's Association.

Pauktuutit Inuit Women of Canada. (2005). Research Report: Applying Inuit cultural approaches in prevention of family violence and abuse. [On-line]. Ottawa, Ontario: Pauktuutit Inuit Women of Canada. Retrieved May 18, 2009 from http://pauktuutit.ca/ pdf/publications/abuse/InuitAbusePrevention_e. pdf.

Schmidt, G. (2008). Geographic location and social work supervision in child welfare. Journal of Public Child Welfare. 2 (1), 91-108.

Schmidt, G. (2000). Remote, northern communities: Implications for social work practice. International Social Work. 43 (3), 337-349.

Sellick, M. \& Delaney, R. (1996). Contextual patterning and metaphors: Issues for northern practitioners. In Delaney, R., Brownlee, K. \& Zapf, M.K. (Eds.), Issues in northern social work practice. Ontario: Centre for Northern Studies, Lakehead University.

Sinclair, R. (2004). Aboriginal social work education in Canada: Decolonizing pedagogy for seventh generation. First Peoples Child and Family Review. 1 (1), 29-61.

Statistics Canada (2006). Nunavut (Code62) (table). Aboriginal population profile. 2006 Census. Statistics Canada Catalogue no. 92-594-XWE. Ottawa. Retrieved March 26, 2011 from http:/ www12.statcan.ca/census-recensement/2006/dp $\mathrm{pd} / \mathrm{prof} / 92 \cdot 594 /$ index.cfm?Lang=E.
Statistics Canada. (2006b). Language: Inuktitut remains strong, but its use has declined. Aboriginal peoples in Canada in 2006: Inuit, Métis and First Nations, 2006 Census: Inuit. Ottawa, Ontario: Industry Canada. Retrieved March 1, 2009 from http:// www12.statcan.ca/english/census06/analysis/ aboriginal/language.cfm.

Tester, F. (2006). Iglutaq (In my room), The implications of homelessness for Inuit: A case study of housing and homelessness in Kinngait, Nunavut territory. Kinngait, Nunavut: The Harvest Society.

Timpson, A. M. (2006). Stretching the concept of representative bureaucracy: The case of Nunavut. International Review of Administrative Sciences. 72 (4), 517-30.

Thompson, J. (2008). Social worker shortage plagues Nunavut. Nunatsiaq News. Retrieved April 13, 2008 from http://www.nunatsiaq. com/archives/2008/804/80404/news / nunavut/80404_1078.htm.

Wharf, B. (1990). Lessons from the social movements. In Wharf, B. (Ed.). Social work and social change in Canada. Toronto, Ontario: McClelland \& Stewart Inc.

Wharf, B. (1979) Ed. Community work in Canada. Toronto, Ontario: McClelland and Stewart.

Windeyer, C. (2010). Nunavut admits Inuit jobs target now a long shot. Nunatsiaq News. Retreived March 26, 2011 from http://www.nunatsiaqonline.ca/ stories/article/280910_nunavut_admits_inuit_ jobs_target_now_a_long_shot/.

Zapf, M. K. (2005a). The spiritual dimension of person and environment: Perspectives from social work and traditional knowledge. International Social Work. 48 (5), 633.642

Zapf, M.K. (1993). Remote practice and culture shock: Social workers moving to isolated northern regions. Social Work. 38 (6), 694-704. 